\title{
PELUANG MENURUT UNCLOS DAN HUKUM POSITIF INDONESIA UNTUK MEMBUKA KEMBALI EKSPOR PASIR LAUT KE SINGAPURA $\Omega$
}

\author{
Tommy Hendra Purwaka \\ Fakultas Hukum Universitas Katolik Indonesia Atma Jaya \\ E-mail: tommy.hendra@atmajaya.ac.id
}

\begin{abstract}
Development of Riau Island Province as one of Indonesian strategic border regions is a must. National and provincial budget used for strengthening the region should obtain finacial support from seasand export revenue. Seasand export revenue, however, could not be expected for the export was banned by the government since 2002. Result of legal research on this matter shows that UNCLOS and Indonesian positive laws give an opportunity to reopen the export. Efforts to reopen the export should be supported by argumentation based on the law of the sea which will be discussed through this paper.
\end{abstract}

Keywords: seasand export, UNCLOS

\begin{abstract}
Abstrak
Pembangunan Provinsi Kepulauan Riau (Kepri) sebagai salah satu wilayah perbatasan strategis Indonesia merupakan suatu keniscayaan. Dana APBN dan APBD untuk memperkuat posisi Kepri secara berkelanjutan perlu didukung dengan dana dari hasil ekspor pasir laut ke Singapura. Permasalahannya adalah bahwa ekspor pasir laut ditutup sejak 2002. Hasil penelitian hukum terhadap permasalahan tersebut menunjukan bahwa UNCLOS dan hukum positif Indonesia memberi peluang kepada pemerintah dan para pemangku kepentingan untuk membuka kembali ekspor pasir laut ke Singapura. Upaya untuk merealisasikan peluang tersebut perlu didukung dengan argumentasi hukum laut yang akan disampaikan melalui tulisan singkat di bawah ini.
\end{abstract}

Kata kunci: ekspor pasir laut, UNCLOS

\section{Pendahuluan}

Pembangunan Kepulauan Riau (selanjutnya disebut Kepri) sebagai salah satu wilayah perbatasan Indonesia yang strategis merupakan suatu keharusan. Kepri sangat strategis bagi Indonesia karena terletak pada Selat Malaka dan Selat Singapura sebagai salah satu selat internasional yang tersibuk di dunia. Kepri juga berhadapan langsung dengan Singapura sebagai salah satu pusat bisnis dan perdagangan dunia. Kepri janganlah sampai tertinggal oleh Johor, Malaysia, yang sedang mengembangkan dirinya untuk bersaing dengan Singapura. Posisi Kepri harus kuat dan mampu bersaing dengan Singapura dan Johor, Malaysia, ${ }^{1}$ dalam lingkungan segi tiga

$\Omega \quad$ Tulisan ini merupakan hasil penelitian dengan Surat Tugas Penelitian dari Lembaga Penelitian dan Pengabdian kepada Masyarakat UNIKA ATMA JAYA Nomor 72/A/III/ LPPM-KP,90.03/01/2014 pertumbuhan Singapura-Johor-Riau (Sijori). Dalam rangka mewujudkan maksud tersebut, Pulau Batam (PP Nomor 46 Tahun 2007), Pulau Bintan (PP Nomor 47 Tahun 2007), dan Pulau Karimun (PP Nomor 48 Tahun 2007) ditetapkan sebagai Kawasan Ekonomi Kusus (selanjutnya disingkat KEK). Pembangunan KEK dan Kepri selama ini didukung dengan dana dari Anggaran Pendapatan dan Belanja Negara (APBN), Anggaran Pendapatan dan Belanja Daerah (APBD), Pendapatan Negara Bukan Pajak (PNBP) dan dari Pendapatan Asli Daerah (PAD). Keempat sumber pendanaan tersebut bukannya tak terbatas, melainkan terbatas, karena penggunaannya bukan hanya un-

Eko Aprilianto, "Dinamika Hubungan Indonesia Dengan Malaysia dan Kaitannya Dengan Tanggung Jawab Negara Dalam Hukum Internasional”, Jurnal Gloria Juris, Vol. 8 No. 1 Edisi Januari-April 2008, Jakarta: Fakultas Hukum Universitas Katolik Indonesia Atma Jaya, hlm. 71. 
tuk membiayai pembangunan KEK dan Kepri. Dalam rangka mengatasi keterbatasan dana tersebut diperlukan dukungan pendanaan dari hasil ekspor pasir laut ke Singapura yang cukup besar jumlahnya yang menurut perhitungan PT Surveyor Indonesia pada tahun 2002 dapat mencapai Rp.50,35 trilyun per tahun selama delapan tahun. Dukungan dana tersebut akan dapat diperoleh, apabila penutupan ekspor pasir laut sejak 2002 dapat dibuka kembali.

Ekspor pasir laut dari seluruh wilayah negara Republik Indonesia dihentikan untuk sementara oleh pemerintah dengan mengeluarkan Keputusan Bersama Menteri Perindustrian dan Perdagangan Nomor 89/MPP/Kep/2/2002, Menteri Kelautan dan Perikanan Nomor SKB.07/ MEN/2002 dan Menteri Negara Lingkungan Hidup Nomor 01/MENLH/2/2002 yang kemudian digantikan dengan Keputusan Menteri Perindustrian dan Perdagangan Nomor 117/ MPP/Kep/2/2003 tentang Penghentian Sementara Ekspor Pasir Laut dari Seluruh Wilayah Indonesia. Alasan penghentian sementara ekspor pasir laut adalah masalah batas wilayah laut antara Indonesia dan Singapura yang belum terselesaikan, masalah kerusakan lingkungan pesisir dan pulau-pulau kecil sebagai akibat penambangan pasir laut yang berdampak pada kelestarian keanegaragaman hayati ${ }^{2}$ di perairan Kepri dan hancurnya harga patokan ekspor (HPE) yang ditetapkan oleh pemerintah karena ulah "mafia pasir laut." Kata sementara yang tertera dalam Keputusan Menteri Perindustrian dan Perdagangan memberi harapan bahwa ekspor pasir laut akan dibuka kembali.

\section{Permasalahan}

Usaha penambangan dan pemasaran ekspor pasir laut dimulai sejak 1970 dan berakhir dengan penutupan sementara pada tahun 2002. Hasil ekspor yang diperkirakan mencapai Rp.50, 35 trilyun per tahun terhenti. Ada tiga alasan untuk menghentikan ekspor pasir laut ke Singa-

Yulia dan Zinatul Ashiqin Zainol, "Melindungi Keanekaragaman Hayati Dalam Kerangka Protokol Nagoya", Jurnal Mimbar Hukum, Vol. 25 No.2 Edisi Juni 2013, Yogyakarta: FH Universitas Gadjah Mada, hlm. 274-279. pura, yaitu masalah batas wilayah laut ${ }^{3}$ Indonesia-Singapura yang belum terselesaikan, masalah kerusakan lingkungan laut, dan masalah tidak tercapainya harga patokan ekspor pasir laut yang menyebabkan negara dirugikan. Pemerintah, bila ingin memperkuat posisi Kepri dalam persaingannya dengan Singapura dan Johor, maka ketiga alasan penutupan tersebut harus diatasi sesuai dengan ketentuan-ketentuan UNCLOS dan hukum positif Indonesia. Persoalannya sekarang adalah bagaimana mengatasi ketiga alasan penutupan tersebut berdasarkan UNCLOS dan hukum positif Indonesia.

\section{Metode Penelitian}

Penelitian ini merupakan penelitian yuridis normatif, yaitu penelitian yang difokuskan pada peluang hukum yang diberikan oleh ketentuan-ketentuan UNCLOS dan hukum positif Indonesia untuk mengupayakan pembukaan kembali ekspor pasir laut ke Singapura. Data yang diperlukan adalah data sekunder yang terdiri dari bahan hukum primer, yaitu UNCLOS dan undangundang yang terkait; bahan hukum sekunder, yaitu ketentuan-ketentuan pelaksanaan undangundang; dan bahan hukum tertier, yaitu uraianuraian terkait dengan bahan hukum primer dan bahan hukum sekunder yang tersebar di beberapa jurnal dan buku hukum. Analisis data dilakukan dengan menggunakan metode komparatif untuk membandingkan keadaan sebelum, pada saat, dan setelah penutupan sementara ekspor pasir laut disertai dengan penafsiran, penalaran, dan argumentasi hukum terhadap ketentuanketentuan UNCLOS dan hukum positif Indonesia.

\section{Pembahasan}

Kondisi Sebelum Penghentian Sementara Kondisi Perbatasan Wilayah Laut

Ekspor pasir laut dari Kepulauan ${ }^{4}$ Riau ke Singapura yang dimulai pada 1970-an merupa-

3 Dina Sunyowati, "Rancangan Model Undang-Undang Penataan Ruang Pesisir dan Laut Daerah Berdasarkan Prinsip Integrated Coastal Zone Management", Jurnal Yustika, Vol. 13 No. 2 Edisi Desember 2010, Surabaya: FH Universitas Surabaya, hlm.151-152.

4 Maria Maya Lestari, "Negara Kepulauan Dalam Konteks Zonasi Hukum Laut”, Jurnal Ilmu Hukum Yustisia: Universitas Andalas, Vol. 19 No. 2 Edisi Juli-Desember 2012, Padang: FH Universitas Andalas, hlm. 179. 
kan salah satu pendorong mengapa kedua negara segera menyelesaikan batas wilayah laut kedua negara di Selat Singapura bagian tengah yang diapit oleh Pulau Singapura dan Pulau Batam pada tahun 1973 (UU Nomor 7 Tahun 1973 tentang Pengesahan Hasil Perundingan GarisGaris Batas Tertentu Antar Indonesia Dengan Singapura di Selat Singapura). Penetapan garis batas tersebut telah memperjelas country of origin dari pasir laut dan dengan demikian perjanjian-perjanjian yang berkaitan dengan ekspor pasir laut yang dibuat oleh para pelaku bisnis ekspor pasir laut memiliki landasan hokumnya.

Bertambah luasnya daratan Singapura secara signifikan sebagai hasil reklamasi pantai dengan menggunakan pasir laut dari Indonesia dalam kurun waktu 32 tahun (1970-2002) dikhawatirkan akan mengubah kedudukan garis pangkal dan memperluas wilayah laut Singapura dengan mengambil wilayah laut Indonesia di Selat Singapura. Berkenaan dengan kekhawatiran tersebut, kegiatan ekspor pasir laut diisukan sebagai "menjual tanah air" ke Singapura dan isu ini berhasil meyakinkan pemerintah untuk menghentikan sementara ekspor pasir laut ke Singapura pada tahun 2002 sampai dengan diselesaikannya masalah batas wilayah laut antara Indonesia dan Singapura.

\section{Kondisi Lingkungan Laut}

Penambangan pasir laut oleh sejumlah dredger (kapal keruk) asing yang tidak ramah lingkungan secara terus menerus selama 32 tahun telah diisukan sebagai penyebab kerusakan lingkungan berupa kekeruhan air laut yang tidak pernah mereda sehingga potensi sumber daya ikan menurun, nelayan dirugikan, serta Pulau Nipa tenggelam. ${ }^{5}$ Pulau Nipa merupakan pulau terluar dimana terletak titik terluar garis pangkal kepulauan Indonesia di Selat Singapura. ${ }^{6} \mathrm{Pu}$ lau tersebut apabila tenggelam, maka salah satu

5 Mita Noverina, "Pendanaan Pembangunan, Degradasi Lingkungan dan Konflik Dalam Pengelolaan Sumber Daya Alam", Jurnal Masyarakat Indonesia, Vol. 38 No. 1 Edisi Juni 2012, Jakarta: LIPI, hlm. 12-15.

6 Awani Irewati, "Dinamika Perbatasan Wilayah Laut di Selat Malaka-Singapura", Jurnal Penelitian Politik, Vol. 8, No. 2 Edisi Juli 2011, Jakarta: LIPI, hlm. 191. titik terluar garis pangkal kepulauan akan hilang. Hilangnya titik terluar tersebut dikhawatirkan akan mengubah tata letak garis pangkal kepulauan yang mempengaruhi pengukuran lebar laut teritorial dan akan mengurangi luas wilayah laut Indonesia. ${ }^{7}$ Perairan Singapura akan bertambah luas seiring dengan pertambahan luas daratan Singapura. Senada dengan keadaan ini, Singapura mengekspor kerusakan lingkungan ke perairan Kepulauan Riau melalui pengoperasian dredger untuk menambang pasir laut dan mengimpornya untuk reklamasi pantai guna memperluas daratannya. ${ }^{8}$ Isu kerusakan lingkungan ini juga menjadi pertimbangan pemerintah untuk menutup sementara ekspor pasir laut pada tahun 2002.

\section{Kondisi Bisnis Pasir Laut}

Eskpor pasir laut melibatkan Jurong Town Corporation (JTC, Singapura), kontraktor (Singapura), pengusaha dredger (asing), dan pemilik KP (Indonesia). JTC bertugas melakukan reklamasi pantai Singapura dengan menggunakan pasir laut dari Kepulauan Riau. Pengadaan pasir laut tersebut ditenderkan oleh JTC kepada para kontraktor. Beberapa kontraktor pemenang tender mengadakan kontrak pengadaan pasir laut dalam jumlah tertentu, harga tertentu dan waktu tertentu dengan nakhoda dredger yang memenuhi persyaratan yang ditetapkan oleh kontraktor. Dredger berlayar ke perairan Kepulauan Riau dan nakhoda dredger membuat perjanjian jual beli dengan para pemilik Kuasa Pertambangan (KP) yang mempunyai izin ekspor dan banyak juga yang melakukan pembelian langsung kepada para pemilik KP dengan pembayaran di lokasi (cash and carry on site). Para nakhoda dredger lazim mempergunakan strategi leave it or take it (tolak atau terima tawaran) dengan harga serendah-rendahnya yang Kenya-

\footnotetext{
Erwin, "Urgensi Perlindungan Pulau-Pulau Terluar Dalam Kaitan Integritas Teritorial Indonesia", Jurnal Pranata Hukum, Vol. 6 No. 2 Edisi Juli 2011, Bandar Lampung: PS MIH Program Pasca Univ. Bandar Lampung, hlm. 183, 189.

8 Elisa Ruozzi, “The Obligation Not to Pollute: From Corollary of State Sovereignty to The Right to A Decent Environment", Indonesian Journal of International Law, Vol. 8 No. 1 Edisi October 2010, Jakarta: Lembaga Pengkajian Hukum Internasional FH UI, hlm. 79-83.
} 
taannya para pemilik KP sulit menolak, karena masih banyak pemilik KP yang tanpa kelengkapan perizinan mau menerima tawaran tersebut.

Keadaan tersebut menimbulkan persaingan tidak sehat, perizinan dibiniskan, penambangan pasir tidak terkendali dan harga patokan ekspor (HPE) yang ditetapkan pemerintah tidak terpenuhi. Sebagai akibatnya, penerimaan pemerintah, pemerintah daerah dan masyarakat menjadi minimal. Negara dirugikan. Pemerintah akhirnya menutup sementara ekspor pasir laut pada tahun 2002.

\section{Kondisi pada saat Penghentian Sementara Landasan Hukum Penghentian Sementara}

Awal penghentian sementara ekspor pasir laut dilakukan pada tahun 2002 dan setelah dievaluasi dan ditata kembali selama tiga bulan ekspor pasir laut akan dibuka kembali. Untuk memperkuat pelaksanaan keputusan tiga menteri tersebut, pemerintah mengeluarkan Keputusan Presiden Nomor 33 Tahun 2002 tentang Pengendalian dan Pengawasan Pengusahaan Pasir Laut dan membentuk Tim Pengendalian dan Pengawasan Pengusahaan Pasir Laut (TP4L), namun oleh karena ketiga Menteri dengan bantuan TP4L tidak berhasil membuka kembali ekspor pasir laut dalam waktu tiga bulan, maka Pemerintah pada tahun 2003 mengeluarkan Keputusan Menteri Perindustrian dan Perdagangan Nomor 117/MPP/Kep/2/2003 tentang Penghentian Sementara Ekspor Pasir Laut Dari Seluruh Wilayah Indonesia tanpa menetapkan batas waktu sampai kapan sementara tersebut diberlakukan dan sebagai konsekuensinya, Keputusan Menteri Perindustrian dan Perdagangan tersebut sampai saat ini masih diberlakukan.

\section{Dampak penghentian sementara}

Dampak yang timbul sebagai akibat penghentian sementara ekspor pasir laut dari Kepulauan Riau ke Singapura adalah sebagai berikut. Pertama, dampak bagi JTC, kontraktor, dan dredger. Semua kontrak dengan Singapura terhenti seketika dan Singapura merasa dirugikan. JTC, oleh karenanya mengenakan denda terhadap para kontraktor sesuai dengan kontrak dan selanjutnya para kontraktor mengenakan denda terhadap para pengusaha dredger sesuai ketentuan kontrak. Denda tersebut dipenuhi oleh para kontraktor dan para pengusaha dredger.

Kedua, dampak bagi pemegang KP. Para pengusaha dredger kemudian menuntut ganti kerugian kepada para pemilik KP, namun para pemilik KP tidak mau membayar ganti kerugian tersebut karena mereka juga merasa dirugikan dengan adanya penutupan sementara ekspor pasir laut. Jual beli pasir laut, disamping itu, dilakukan dengan cara cash and carry on site. Tidak adanya dredger yang membeli pasir laut, maka izin KP berakhir dengan sendirinya dan pemilik tidak memperpanjang, serta wilayah penambangan pasir menjadi wilayah tak ber-KP.

Ketiga, dampak bagi Pemerintah Indonesia. Dalam kaitan dengan kerugian para pelaku bisnis ekspor pasir laut tersebut di atas, pemerintah sama sekali tidak dapat dituntut oleh para pelaku bisnis karena penutupan sementara tersebut dilakukan untuk melindungi kepentingan nasional Indonesia. Pemerintah tidak terikat dengan berbagai macam kontrak, semetara itu perilaku para pihak yang terikat kontrak telah menghancurkan HPE dan kepentingan nasional Indonesia.

\section{Kondisi Setelah Penutupan Sementara dan Pe- luang Buka Kembali}

Kondisi setelah penutupan sementara menunjukkan bahwa ekspor pasir laut sejak 2002 sampai saat ini belum dibuka kembali, walaupun beberapa permasalahan yang dipergunakan untuk menutup sementara ekspor pasir laut sudah diselesaikan berdasarkan UNCLOS dan hukum positif Indonesia yang terkait. UNCLOS dan hukum positif Indonesia dalam kaitan ini dapat dikatakan sebagai pemberi peluang untuk membuka kembali ekspor pasir laut ke Singapura.

Permasalahan garis batas wilayah laut di bagian tengah dan di bagian barat Selat Singapura telah diselesaikan oleh kedua negara dengan berbasis pada garis pangkal, dimana garis pangkal Singapura tidak berubah walau wilayah pantainya bertambah luas. Program perlindung- 
an dan pelestarian lingkungan ${ }^{9}$ perairan Kepulauan Riau telah dibuat dan dilaksanakan oleh Pemerintah Indonesia, antara lain dengan reklamasi Pulau Nipa dan pendalaman alur-alur untuk keselamatan pelayaran.

\section{Peluang Menurut UNCLOS Penetapan Garis Pangkal}

Singapura merupakan negara pulau (is(and state) dan sekaligus juga negara pelabuhan (port state) dengan kondisi geografis yang kurang menguntungkan, karena hanya memiliki perairan pedalaman, laut territorial, dan dasar laut (bukan landas kontinen) yang sempit (geographically disadvantaged state). Namun demikian, Singapura sangat diuntungkan dengan posisinya sebagai negara pelabuhan yang terletak pada Selat Malaka-Singapura yang merupakan salah satu jalur pelayaran internasional (straits for international navigation) yang tersibuk di dunia. Posisi tersebut telah menjadikan Singapura sebagai salah satu pusat industri jasa di dunia.

Singapura, untuk meningkatkan fungsinya sebagai negara pelabuhan dan pusat industri jasa dunia, memerlukan perluasan lahan melalui reklamasi wilayah pantai dengan pasir laut dari Kepulauan Riau, Indonesia. Perubahan wilayah pantai ini tidak boleh dijadikan dasar untuk menetapkan garis pangkal. Garis pangkal adalah garis yang menghubungan titik-titik alamiah dan bukan buatan manusia serta tidak boleh menyimpang dari konfigurasi wilayah negara (Pasal 5, Pasal 7, dan Pasal 47 UNCLOS). Ketentuan Pasal 7 UNCLOS, dalam kaitan ini, memberi pengecualian bahwa garis-garis yang dibentuk dengan menghubungkan titik-titik dari fasilitas-fasilitas buatan manusia yang secara internasional diakui sebagi bagian permanen dari kegiatan kepelabuhanan dapat dipergunakan sebagai garis pangkal lurus. Singapura sebagai negara pelabuhan menggunakan Pasal 7 UNCLOS untuk menetapkan garis pangkalnya. Garis pangkal Singapura yang telah ditetapkan berdasarkan ketentuanketentuan UNCLOS tersebut dan dipergunakan

Sutoyo, "Paradigma Perlindungan Lingkungan Hidup”, Adil Jurnal Hukum, Vol. 4 No. 1 Edisi Juli 2013, Jakarta: Fakultas Hukum Universitas YARSI, hlm.192-193. dalam penyelesaian batas wilayah laut di bagian tengah Selat Singapura pada tahun 1973 tidak boleh dan tidak akan berubah dan tetap dipakai sebagai landasan untuk menyelesaikan batas wilayah laut di bagian barat dan bigian timur Selat Singapura. Dalam kaitan ini dan sebagai respon tidak langsung terhadap kekhawatiran dari beberapa pihak di Indonesia, Menteri Luar Negeri Singapura sebelum mengadakan perundingan dengan Indonesia tentang batas laut di sebelah barat pada tahun 2009 sudah menegaskan kepada Parlemen Singapura bahwa reklamasi pantai tidak akan mempengaruhi garis batas laut yang telah ditetapkan pada tahun 1973 dan yang akan dirundingkan kemudian.

\section{Penyelesaian Batas Laut Territorial}

Batas wilayah laut antara Indonesia dan Singapura di bagian tengah Selat Singapura sudah diselesaikan pada tahun 1973 berdasarkan Pasal 15 UNCLOS. Perundingan perbatasan wilayah laut di luar persetujuan tahun 1973 harus dibicarakan oleh tiga negara, yaitu Indonesia, Singapura dan Malaysia karena ada satu titik di ujung barat dan satu titik diujung timur Selat Singapura yang merupakan three junction point, yaitu satu titik yang menentukan penarikan batas wilayah laut antar ketiga negara. ${ }^{10}$ Penyelesaian batas wilayah laut di bagian barat dan timur Selat Singapura tersebut diupayakan tidak sampai mencakup ke dua three junction point tersebut.

Penyelesaian batas wilayah laut di bagian barat dan timur Selat Singapura, disamping itu tidak semudah penyelesaian di bagian tengah, karena Indonesia mengkaitkan dengan kepentingannya yaitu agar Singapura mau menandatangani persetujuan ekstradisi dan di lain pihak Singapura mengkaitkan dengan kepentingannya yaitu agar Indonesia mau memperpanjang Defense Cooperation Arrangement (DCA). Indonesia berkepentingan atas persetujuan ekstradisi tersebut karena Indonesia menginginkan adanya kemudahan yang diberikan oleh Singapura da-

\footnotetext{
- Mahendra Putra Karunia, “Upaya Penanganan Permasalahan Maritim Republik Indonesia", Risalah Hukum: Jurnal Hukum, Vol. 2 No. 1 Edisi Juni 2006, Samarinda: Fakultas Hukum Mulawarman.
} 
lam malakukan ekstradisi terhadap para pelaku korupsi dan pelaku kejahatan lainnya berkewarganegaraan Indonesia yang bersembunyi di Singapura. Singapura, di lain pihak, berkepentingan, agar Indonesia mau memperpanjang persetujuan DCA sehingga militer Singapura bersama Tentara Nasional Indonesia dapat melakukan latihan militer dengan menggunakan lahan tertentu di wilayah Indonesia yang ditetapkan oleh Indonesia. Kepentingan tersebut, apabila dapat diselesaikan, maka masalah garis batas wilayah laut kedua negara akan dapat diselesaikan.

Perundingan penyelesaian batas wilayah laut di bagian barat Selat Singapura dapat terselenggara dan selesai dengan baik kemungkinan dikarenakan persoalan ekstradisi dan DCA telah dapat diselesaikan, sehingga dengan demikian dapat dipahami bahwa pernyataan Menteri Luar Negeri Singapura tentang garis pangkal tersebut di atas, serta terselesaikannya persoalan ekstra-disi dan DCA telah menjadi pertimbangan bagi kedua negara untuk menyelesaikan garis batas wilayah laut di bagian barat Selat Singapura. Pemerintah Indonesia kemudian meratifikasi persetujuan tahun 2009 tentang perbatasan laut di Selat Singapura bagian barat pada bulan Mei 2010. Sementara itu, perundingan perbatasan laut di Selat Singapura bagian timur saat ini sedang dipersiapkan. ${ }^{11}$ Persetujuan garis batas tersebut menunjukkan bahwa perluasan pantai Singapura tidak mempengaruhi batas-batas wilayah laut antara Indonesia dan Singapura.

\section{Perlindungan Lingkungan Laut}

Usaha penambangan pasir laut tidak dipungkiri telah mengakibatkan terjadinya kekeruhan perairan. Namun demikian, kekeruhan perairan tidak hanya disebabkan oleh penambangan pasir laut, namun juga oleh kepadatan lalu lintas kapal-kapal tangker (VLCC, UVLCC) di Selat Singapura yang rata-rata mencapai 56 kapal per hari pada tahun 2007 dan menurut Awani Irewati (2011) mencapai 200 kapal per hari termasuk VLCC dan UVLCC. Kapal-kapal tersebut berlalu lintas melalui Selat Singapura yang sangat sempit di Phillips Channel dengan lebar 800 meter, Buffalo Rock dengan lebar 532 meter, dan Pulau Batubehanti dengan lebar 800 meter ${ }^{12}$ sehingga olah gerak atau manuver kapal dan perputaran propelernya menimbulkan kekeruhan di ketiga channel tersebut dan perairan sekitarnya. Pergerakkan gelombang pasir di dasar laut (bottom sand movement) juga menimbulkan kekeruhan perairan.

Pasir laut yang ada dan tersebar di perairan Kepulauan Riau berasal dari jutaan meter kubik bottom sand movement yang bergerak dari Samudera Hindia dan Laut Cina Selatan masuk ke perairan Kepulauan Riau. Sifat geologis pasir laut yang banyak mengandung kapur (kalsium) pasti berbeda dari pasir daratan pulau-pulau yang ada di Kepulauan Riau yang banyak mengandung bauksit. Hal ini membuktikan bahwa pasir laut tidak berasal dari pulau-pulau di Kepulauan Riau. Pasir laut bukan bagian pulau yang longsor ke dasar laut yang kemudian dimanfaatkan sebagai usaha penambangan pasir laut. Isu pulau tenggelam oleh karenanya tidak memiliki korelasi langsung dengan usaha penambangan pasir laut. Kenyataan menunjukan bahwa beberapa pulau yang mengalami kerusakan lingkungan karena tanah/pasir daratnya dikeruk dalam jumlah besar, sehingga daratan pulau habis dan lama kelamaan pulau tersebut tenggelam.

Pulau Nipa yang diisukan tenggelam adalah pulau yang sejak dulu terdiri dari dua batu karang yang senantiasa berada di atas permukaan air dengan hamparan pantai karang dangkal yang senantiasa berada di bawah permukaan air. Sejak sebelum usaha penambangan pasir laut dimulai pada tahun 1970-an sampai saat ini kondisi Pulau Nipa adalah seperti itu. Peta-peta Pulau Nipa yang dikeluarkan oleh Dinas Hidrografi TNI AL dari tahun 1970-an sampai dengan kondisi Pulau Nipa sebelum direklamasi pada tahun 2010 menunjukkan tidak adanya perubahan fisik pulau. Kondisi fisik pulau yang ada saat ini, dengan demikian bukan merupakan dampak dari kegiatan usaha penambangan pasir laut. Kenyataan lainya juga menunjukkan bahwa sifat geologis pasir laut tidak sama dengan sifat geologis

11 Awani Irewati, loc.cit, hlm. 192.

12 Ibid, hlm. 186. 
batu karang Pulau Nipa. Sifat geologinya bila sama, maka pasir laut yang ada di sekitar Pulau Nipa merupakan longsoran dari batu karang Pulau Nipa. Pulau Nipa saat ini sudah direklamasi dan dijadikan Pos Laut oleh Pemerintah Daerah, TNI AL, dan Kepolisian Negara Republik Indonesia.

Berdasarkan ketentuan Pasal 192 dan Pasal 197 UNCLOS, Indonesia dan Singapura secara sendiri-sendiri maupun bersama-sama atau bekerjasama dengan lembaga internasional wajib untuk melakukan program perlindungan dan pelestarian lingkungan laut di Selat Singapura dalam rangka mengatasi masalah tersebut di atas. Indonesia secara sendiri telah membuat program tersebut di perairan Kepulauan Riau berdasarkan UU Nomor 23 Tahun 1997 tentang Pengelolaan Lingkungan Hidup dan kemudian disempurnakan dengan mengacu pada UU Nomor 32 Tahun 2009 tentang Perlindungan dan Pengelolaan Lingkungan Hidup. Program tersebut dilaksanakan untuk melakukan pencegahan dan penanggulangan pencemaran yang berasal dari darat (land base pollution) dan yang berasal dari kapal (vessel base pollution) serta limbah yang dibuang ke perairan dan/atau ke daratan pulau-pulau (dumping). Program tersebut juga disiapkan untuk memonitor, mencegah, dan menanggulangi pencemaran dan kerusakan lingkungan perairan sebagai akibat pengoperasian dredger untuk melakukan kegiatan penambangan pasir laut.

\section{Keselamatan Pelayaran}

Selama penghentian sementara ekspor pasir laut dari tahun 2002 sampai saat ini, kegiatan dredger (kapal keruk) juga berhenti. Hal ini berakibat beberapa lokasi pelabuhan dan alur-alur pelayaran mengalami pendangkalan yang membahayakan pelayaran. Ketentuan $\mathrm{Pa}$ sal 41 dan Pasal 42 UNCLOS mewajibkan negaranegara pantai yang membatasi selat untuk pelayaran internasional agar menjamin keselamatan pelayaran, antara lain melalui pengerukan lokasi pelabuhan dan alur-alur pelayaran. Biaya yang kegiatan pengerukan tersebut sudah barang tentu dibebankan kepada APBN Indonesia. Ekspor pasir laut bila dibuka kembali, maka bia- ya pengerukan yang mahal dapat dibebankan kepada pendapatan dari hasil ekspor pasir laut.

\section{Peluang Menurut Hukum Positif Indonesia Hak Rakyat Berdasarkan Konstitusi}

Pasir laut sebagai sumber daya alam yang mengendap di wilayah pesisir ${ }^{13}$ dan perairan laut Kepulauan Riau menurut Pasal 33 ayat (3) UUD 1945 dikuasai oleh negara dan dipergunakan untuk sebesar-besar kemakmuran rakyat. Bunyi Pasal 33 ayat (3) UUD 1945 ini senada dengan Pasal 136 UNCLOS yang mengatakan bahwa dasar laut internasional dan kekayaan alam yang terkandung di dalamnya adalah milik anak cucu (common heritage of mankind). Pengusahaan pasir laut, merupakan hak konstitusional rakyat dan Provinsi Kepulauan Riau. ${ }^{14}$ Pasir laut dapat digunakan untuk mensejahterakan rakyat Indonesia, khususnya yang bermukim di Provinsi Kepulauan Riau.

Pasir laut sebagai sumber kesejahteraan rakyat ${ }^{15}$ dapat digambarkan dari aspek ekonomi sebagai berikut. Menurut data yang didapatkan oleh PT Surveyor Indonesia pada tahun 2002, Singapura membutuhkan pasir laut sebanyak 1,8 milyar $\mathrm{m}^{3}$ untuk kegiatan reklamasi tahun 20032010. Kebutuhan tersebut sampai saat ini masih tetap ada dan perlu segera dipenuhi. Indonesia, jika dapat memasok kebutuhan tersebut dengan harga SingD $30 / \mathrm{m}^{3}$ (SingD $1=\mathrm{Rp}$ 6.000), maka Indonesia akan memperoleh hasil penjualan ekspor pasir laut sebesar Rp 50,35 trilyun per tahun selama delapan tahun. Dalam rangka memperoleh pendapatan sebesar itu sebagai akibat dibukanya kembali ekspor pasir laut, maka pemerintah Indonesia disarankan bekerjasama dengan pemerintah Singapura untuk memperbaiki tata niaga pasir laut melalui penerapan kebijakan one gate policy. Kebijakan satu pintu ini dimaksudkan untuk menyelesaikan masalah per-

3 Nurul Fajri Chikmawati, "Pengelolaan Wilayah Pesisir dan Pulau-Pulau Kecil di Indonesia (Dalam Perspektif Perlindungan Hukum Bagi Hak-Hak Ekonomi Masyarakat)", Adil Jurnal Hukum, Vol. 4 No. 2 Edisi Desember 2013, Jakarta: FH Universitas YARSI, hlm. 396-397.

14 Nurul Fajri Chikmawati, loc.cit, hlm. 397.

15 Finalia dan Magdalena Zebua, "Mengembalikan Pemanfaatan Sumber Daya Alam Kepada Masyarakat (Studi Kasus di Bangka)", Jurnal Dialogia luridica, Vol. 3 No. 1 Edisi November 2011, Bandung: FH Universitas Kristen Maranatha, hlm. 130-131. 
izinan dan masalah lainnya di bawah satu atap, mengontrol interaksi supply dan demand, memonitor lalu lintas ekspor dan pembayaran hasil penjualan pasir laut, serta melakukan pemantauan, pengendalian, pengamatan lapangan dan evaluasi terhadap kelestarian lingkungan perairan di Kepulauan Riau.

Pengembangan Kawasan Ekonomi Khusus Batam-Bintan-Karimun, perluasan Tanjung Priok, dan pembangunan Marunda Center sebagai hubport, memerlukan pasir laut untuk reklamasi dalam jumlah besar. Kebutuhan tersebut di atas akan dapat dipenuhi oleh sumber daya pasir laut di perairan Kepulauan Riau secara berkelanjutan, karena pasir laut yang berada di dasar laut perairan Kepulauan Riau merupakan sumber daya alam terbarukan yang terbentuk secara alami dan berkelanjutan dari gelombang pasir dasar laut yang bergerak dari Samudera Hindia melalui Selat Malaka dan dari Laut China Selatan melalui perairan Natuna ke perairan Kepulauan Riau. Bila sumber daya pasir laut tidak dimanfaatkan, maka pasir laut tersebut akan dapat menghambat alur-alur pelayaran dan pengerukannya akan menjadi beban pemerintah.

\section{Evaluasi Landasan Hukum Peraturan Penutup- an Ekspor Pasir Laut}

Kata "sementara" dalam judul Keputusan Menteri Perindustrian dan Perdagangan Nomor 117/ MPP/Kep/2/2003 tentang Penghentian Sementara Ekspor Pasir Laut Dari Seluruh Wilayah Indonesia mengandung ketidakpastian hukum apabila diberlakukan tanpa batas waktu. Pemerintah, oleh karenanya wajib memberi ketegasan apakah mau dibuka kembali atau ditutup untuk seterusnya. Walaupun demikian, kata "sementara" dikaitkan dengan terselesaikannya batas maritim di bagian barat dan tengah antara Indonesia dan Singapura, tersusunnya program perlindungan dan pengelolaan lingkungan laut Kepulauan Riau, terselesaikannya reklamasi Pulau Nipa, dan tersusunnya tata niaga pasir laut yang baru untuk Kepulauan Riau telah memberi harapan bahwa penghentian sementara akan digantikan dengan pembukaan kembali ekspor pasir laut.

\section{Kelayakan hukum}

Upaya untuk menggiatkan kembali bisnis pasir laut di Kepulauan Riau melalui pemberian izin ekspor ke Singapura dapat dikatakan memenuhi kelayakan hukum apa bila dapat meningkatkan kepastian hukum, menjamin terwujudnya keadilan, dan menjunjung tinggi nilai-nilai kebenaran. Ketiga aspek kelayakan hukum tersebut dapat diuraikan sebagai berikut.

Pertama, aspek kepastian hukum: Pencabutan Keputusan Menteri Perindustrian dan Perdagangan Nomor 117/ MPP/Kep/2/2003 tentang Penghentian Sementara Ekspor Pasir Laut akan memberikan kepastian hukum tentang diizinkannya kembali perdagangan pasir laut ke Singapura. Perdagangan pasir laut ke Singapura dimulai pada tahun 1970-an dan telah berlangsung selama 32 tahun tanpa ada masalah. Namun kemudian pada tahun 2003 secara tiba-tiba berdasarkan ketiga alasan tersebut di atas, ekspor pasir laut dihentikan untuk sementara. Kesementaraan tersebut berlangsung terus hingga saat ini tanpa ada kepastian apakah ekspor akan dibuka kem-bali atau akan ditutup untuk seterusnya. Penulis mengusulkan agar pemerintah membuka kembali ekspor pasir laut untuk memberikan kepastian hukum kepada para pelaku bisnis pasir laut dan kepada masyarakat, khususnya masyarakat Kepulauan Riau.

Kedua, aspek keadilan. Ekspor pasir laut merupakan salah satu sumber penting Pendapatan Asli Daerah (PAD) Provinsi Kepulauan Riau. Hasil ekspor tersebut sangat didambakan oleh masyarakat Kepulauan Riau untuk memacu pertumbuhan ekonomi melalui pembangunan daerah. Dalam hal ini, adalah tidak adil apabila pemerintah memutuskan untuk menutup ekspor pasir laut untuk selamanya, karena di masa lalu masyarakat Kepulauan Riau tidak menikmati hasil penjualan pasir laut ke Singapura. Masyarakat terpaksa harus memikul beban pencemaran dan kerusakan lingkungan tanpa diberi peluang pembiayaan yang memadai untuk memperbaiki dan merehabilitasi kerusakan lingkungan tersebut. Pencabutan Keputusan Menteri Perindustrian dan Perdagangan tahun 2003 tentang Penghentian Sementara Ekspor Pasir Laut akan dapat 
memenuhi rasa keadilan masyarakat Kepulauan Riau.

Kedua, aspek kebenaran. Alasan-alasan yang digunakan untuk melakukan penutupan sementara ternyata mengandung ketidakjelasan yang tinggi, sehingga diragukan kebenarannya. Sebagai contoh adalah kenyataan tidak adanya kesamaan sifat geologi tanah daratan pulau dan pasir laut seharusnya tidak perlu sampai menimbulkan isu pulau tenggelam yang dituduhkan sebagai akibat penambangan pasir laut. Kondisi fisik Pulau Nipah menurut penduduk setempat sejak dahulu sampai sebelum direklamasi tidak mengalami banyak perubahan, walaupun demikian, Pulau Nipa diisukan sebagai pulau tenggelam akibat penambangan pasir laut. Pulau tenggelam yang terjadi di perairan Kepulauan Riau bukan disebabkan oleh penambangan pasir laut, melainkan oleh penambangan pasir darat yang ada di pulau tersebut. Isu pulau tenggelam sebenarnya kurang tepat untuk dijadikan alasan penghentian sementara eskpor pasir laut ke Singapura karena tidak sesuai dengan kenyataan. Pencabutan Keputusan Menteri Perindustrian dan Perdagangan tahun 2003 tentang Penghentian Sementara Ekspor Pasir Laut, oleh karenanya akan dapat memenuhi nilai-nilai kebenaran.

\section{Penutup}

Simpulan

UNCLOS dan hukum positif Indonesia secara jelas memberikan peluang untuk dijadikan landasan hukum bagi pembukaan kembali ekspor pasir laut dari Kepulauan Riau ke Singapura.

\section{Saran}

Penulis memberikan saran sebagai berikut. Pertama, Pemerintah disarakan untuk segera memformulasikan ketentuan-ketentuan UNCLOS dan hukum positif Indonesia terkait yang akan dijadikan landasan hukum bagi pembukaan kembali ekspor pasir laut dari Kepri ke Singapura; dan kedua, berdasarkan landasan hukum yang dimaksudkan di atas pemerintah disarankan membuka kembali ekspor pasir laut guna memenuhi tujuan Pasal 33 ayat (3) UUD 1945, yaitu untuk mewujudkan sebesar-besar kemakmuran rakyat melalui pengelolaan penambangan dan pemasaran pasir laut dari Kepri ke Singapura.

\section{Daftar Pustaka}

Aprilianto, Eko. "Dinamika Hubungan Indonesia dengan Malaysia dan Kaitannya dengan Tanggung Jawab Negara dalam Hukum Internasional". Jurnal Gloria Yuris. Vol. 8 No. 1 Edisi Januari-April 2008. Jakarta: FH Universitas Katolik Indonesia Atma Jaya;

Chikmawati, Nurul Fajri. "Pengelolaan Wilayah Pesisir dan Pulau-Pulau Kecil di Indonesia (Dalam Perspektif Perlindungan Hukum Bagi Hak-Hak Ekonomi Masyarakat)". Adil Jurnal Hukum. Vol. 4 No. 2 Edisi Desember 2013. Jakarta: FH Universitas YARSI;

Erwin. "Urgensi Perlindungan Pulau-Pulau Terluar Dalam Kaitan Integritas Teritorial Indonesia". Jurnal Pranata Hukum. Bandar Lampung: PS MIH Program Pasca Sarjana Universitas Bandar Lampung;

Finalia dan Magdalena Zebua. "Mengembalikan Pemanfaatan Sumber Daya Alam Kepada Masyarakat”. Jurnal Diologia luridica. Vol. 3 No. 1 Edisi November 2011. Bandung: FH Universitas Kristen Maranatha;

Irewati, Awani. "Dinamika Perbatasan Wilayah Laut di Selat Malaka-Singapura". Jurnal Penelitian Politik. Vol. 8, No. 2, 2011 Edisi Juli 2011. Jakarta: LIPI;

Karunia, Mahendra Putra. "Upaya Penanganan Permasalahan Maritim Republik Indonesia”. Risalah Hukum: Jurnal Hukum. Vol. 2 No. 1 Edisi Juni 2006. Samarinda: Fakultas Hukum Mulawarman;

Lestari, Maria Maya. "Negara Kepulauan Dalam Konteks Zonasi Hukum Laut". Jurnal Il-mu Hukum Yustisia: Universitas Andalas. Vol. 19 No. 2 Edisi Juli-Desember 2012. Padang: FH Universitas An-dalas;

Noveria, Mita. “Pendanaan Pembangunan, Degradasi Lingkungan dan Konflik Dalam Pengelolaan Sumber Daya Alam". Jurnal Masyarakat Indonesia, Vol. 38, No. 1, Juni 2012. Jakarta: LIPI;

Rouzzi, Elisa. "The Obligation Not to Pollute: From Corollary of State Sovereignty to The Right to a Decent Environment". Indonesian Journal of International Law. Vol. 8, No. 1, Oktober 2010. Jakarta: Lembaga Pengkajian Hukum Internasional FH Universitas Indonesia; 
Sunyowati, Dina. "Rancangan Model Undang-Undang Penataan Ruang Pesisir dan Laut Daerah Berdasarkan Prinsip Integrated Coastal Management". Jurnal Yustika. Vol. 13 No. 2 Edisi Desember 2010. Surabaya: FH Universitas Surabaya;
Sutoyo. "Paradigma Perlindungan Lingkungan Hidup”. Adil Jurnal Hukum. Vol. 4 No. 1 Edisi Juli 2013. Jakarta: FH Univ. YARSI;

Yulia dan Zainol, Zinatul Ashiqin. "Melindungi Keanekaragaman Hayati Dalam Kerang-ka Protokol Nagoya". Jurnal Mimbar Hukum. Vol. 25 No. 2 Edisi Juni 2013. Yogyakarta: Fakultas Hukum Universitas Gadjah Mada. 